\title{
Development of Motion Creativity and Songs for Stimulating Children's Social Emotional at Kindergarten in Palu Sulawesi
}

\author{
Andi Agusniatih ${ }^{1}$ and Besse Nirmala ${ }^{2}$ \\ ${ }^{1}$ Early Chidlhood Education Department, University of Tadulako,Palu, Indonesia, andiagusniatih@gmail.com \\ ${ }^{2}$ Early Childhood Education Department, University of Tadulako, Palu, Indonesia
}

\begin{abstract}
This research aims to develop creativity in stimulating the movement and social emotional song through movement and song in kindergarten Widyatama with TK Samporoa. The subjects were 20 children. Model development of this study using the model of the Borg and Gall. Data collection through observation, documentation and interviews and pretest and posttest to see the social development of a child's emotional. Based on the results of field trials limited to motion and obtained a song worthy of 3.34 to the criteria, the results of extensive field trial gained an average of 3.52 with a decent criteria, while the study results omparasi obtained a value of $0.007<0.05$ thus there is a difference significantly between the average results posttest control group and groups of instruments.
\end{abstract}

Keywords: Creativity, movement and song, children's social emotional

\section{INTRODUCTION}

At an early age 0-6 years, the brain develops very rapidly up to 80 percent. At that age the brain to receive and absorb various kinds of information, did not see the good and the bad. A study conducted by an expert in child development and behavior of Americans named Brazelton states that children's experiences in the first months and years of life will determine whether the child will be able to face the challenges in life and whether the child will show the passion to learn and succeed in the workplace. Positive social behavior is a reflection of an individual adult social behavior in a child. In line with the statement of Elizabeth Hurlock,

Social emotional development is important for children. There are some fundamental things that encourage the emotional importance of social development, the first, increasingly complex problems around the child's life, including the development of science and technology that much pressure on the child, and affect the child's social and emotional development. Second, is the cultivation of awareness that children are practitioners and future investments need to be prepared to the fullest, both aspects of emotional development and social skills, the third since the age range important in children is limited. So, must be facilitated as optimal as possible so that no one missed any phase, fourth child was not able to live and thrive with sheer IQ, but EQ is more urgently needed as the provision of life,

There is the same tendency in the whole world, that the current generation has more emotional difficulties than in previous generations so the impact on social skills. Thus, there needs to be an effort to improve emotional intelligence, that efforts aimed at developing and improving the quality of children's emotional to be able to recognize your feelings and the feelings of others, able to motivate yourself and be able to manage your emotions and social behavior for the better. The young generation is the generation that is essential for the progress of a nation. Problems that occur in the country of Indonesia is rooted personality that is not sensitive to the rights and obligations owned by themselves and others. Corruption and other crimes begins the process of life is not executed carefully and think only of yourself. A sociologist sometimes see the phenomenon of corruption as an aberration. A person tends to do things that deviate when a person feels that it is more profitable perversity. Based on the above description need their attention to the quality of the nation's future. This is why the authors to examine the social aspects of the child's emotional development through movement and song. Based on the above description need their attention to the quality of the nation's future. This is why the authors to examine the social aspects of the child's emotional development through movement and song. Based on the above description need their attention to the quality of the nation's future. This is why the authors to examine the social aspects of the child's emotional development through movement and song.

Development of social and emotional aspects are very important children are stimulated since early childhood because at this time is a sensitive period of the child as a base or foundation for further developments. If developments in the future are not given the appropriate stimulus it will affect the subsequent development of the child's social and emotional especially important to do with 
how to interact in solving a problem and interaction with others. In addition, social development is very important for a child's emotional development of children in the mix, interact, solve problems and socialize with people around him.

Hurlock (2009: 250) said that social development means the acquisition of the ability to behave in accordance with social demands. Social demands here signifying that they must comply with and approved by others. The opinion was reinforced by Minet (1994) said that social development is a process of learning abilities of behavior copied from within the family and following similar examples in the entire world.

Early childhood development according to Santoso (2004: 82) is the process of change sustainable progressively from the time of birth until the age of 8 years. In this case the child has a very rapid growth and development in terms of physical, cognitive, language, social, emotional and other aspects of personality. Although each of the development are considered separately, but it should be understood that each area of the development is part of the overall development and unity of a unit consisting of many aspects of development Santoso (2004: 84).

Social development according to Aisha (2011: 9.2) is the process of learning and behavior related to the individual to live as part of the group. In the social development of the child is required to have the necessary skills to social demands in which the child resides. Social demands in question is either a child can socialize with the appropriate stage of development and age, and tends to be a very outgoing child.

Erik Erikson's theory in Slavin (2011: 93) on the development of personal and social remind that during the preschool years, children's personality resolves the crisis between the initiative versus guilt. The success of the children finish this stage produces a sense of initiative and ambition reinforced by a reasonable understanding of what is allowed. Early childhood educators can encourage the completion of this with the members the opportunity to children to take the initiative, challenged and successful.

Motion as the media said, in the sense of early childhood development, of course, will vary with movements that can be done by adults. Motor development in early childhood can be measured based on the category into multiple phases of psychomotor development, Rachmi et al (2008: 6.5).

Movement activities and songs together will make the children to interact fairly and encouraging. On this occasion, the child will create important aspects that are useful for children's life skills, such as teamwork, collaboration and tasks of the group with his friends. This activity will greatly help teachers encourage children who have difficulty to interact. The experience will give you the motivation and context for children's skills to interact. In addition, these activities can develop mutual tolerance, forgiving, and mutual respect among peers.

\section{RESEARCH METHODS}

\section{A. Types of research}

This research uses research and development (R \& D). This research aims to develop children's creativity and songs motion an effective, attractive, high quality, practical, and valid. The approach in this study is the research development with the procedure adapted from Borg and Gall, 1989 (Sukmadinata, 2012: 169-170).

B. Place and time of research

This study uses a sampling technique purposive sampling. Purposive sampling site selection study interpreted that the location has been determined since the beginning of the characteristics based research needs. The location of the research that has been done is in kindergarten Melati tondo, Kindergarten Samporoa and TK Widyatama Tadulako.

The research was conducted from April to November 2018.

\section{Research subject}

The subject in this research and development that is 5-6 years old children in group B were a total of 20 children.

\section{Research procedure}

The procedure is to adapt the research and development of the model of development of Borg and Gall. The procedure of development is as follows: 1) analysis of the products developed, 2) analysis of needs, 3) early product development, 4) develop the instrument, 5) carry out expert validation material, language and media, 6) revise, 7) test limited field and revisions, 8) wider field testing and revision, 9) operational field testing and revision, 10) evaluation of disaster mitigation understanding of children, and 11) the final product.

\section{E. Data collection technique}

Data was collected through observation, interview and documentation and pretest-posttest to see the social development of a child's emotional.

\section{F. Data analysis technique}

Data test results and track the effectiveness of motion analyzed by using independent sample tests with previous test of homogeneity and normality. Then test the attractiveness and practicality with analysis presentation. Product movement and song before tested prior review by the validator which will then be assessed for feasibility.

\section{RESULT AND DISCUSSION}

Data and information obtained through preliminary studies, limited field trial, extensive field trials and operational field trials. The exposure of the research is as follows.

1. Preliminary Study Results

Based on the preliminary study results showed that teachers rarely create children's songs along with the movement. Teachers only implement the songs that already exists. Then the songs children are rarely created by the singer-singer so the kids now, especially in the city of Palu more memorize the songs of adults and Korean songs rather than 
songs that fit his age. Therefore, the researchers took the initiative to develop the creativity of motion and songs involving 10 educators were creative in composing songs for the child's emotional social stimulation.

2. Early Product Development

In the early stages, while the results of the initial product development creativity and track motion is as follows.

a) Making the manuscript rhymes

In the event of drafting rhymes, the development team invited 10 educators to create three songs on the theme of plants. The song created from the lyrics that contain elements of moral values and character that is easily understood by children.

b) Making the rhythm of the song In this activity, the development team involving musicians or composers to create the rhythm accompaniment tracks.

c) movement songs

The development team formulates movements that can be done while singing. This movement is made simple which can be directly implemented by the children.

d) Motion Books and Songs

Products outcome of this development in the form of a book in which there are lyrics and the accompanying drawings movements.

3. Results Validation

After the results of the initial product development, further due diligence by the experts of material, language, and media

a. Validation Expert Content

Validation matter experts involved one validator that Prodi PG ECD lecturers Tadulako. The results of the validation by the instrument of validation that obtained a mean score of 3.51 with a decent criteria. Advice from expert validator material is made shorter songs.

b. Validation Linguists

Validation linguists involved one validator of language education Prodi Tadulako. The results of the validation by the instrument of validation that obtained a mean score of 3.42 with a decent criteria. Suggestions of validator linguists that the language used is simple and easily understood by children. c. Art Expert Validation

Validation of art experts involved one validator of lecturers backgrounds S2 Art Music Tadulako. Art expert validation results received mean score is 3.34 with the criteria are eligible to be tested. The suggestion from the media validator which must be in accordance with the rhythm of the song lyrics.

1. Limited Field Trial

Limited field trial by applying the motion and song at an initial meeting in kindergarten Melati tondo involving 20 children. Results limited field trial gained an average of 3.34 with a decent criteria. The revision of this limited field trials are still too difficult movement to be imitated by younger children. Step follow-up that the development team revised the movements become more simply movement.

2. Field Trial Size

On the activities of the broader field trial involving 20 children in kindergarten Samporoa. The results of the trial gained an average of $3.52 \%$ with a decent criteria. On the activities of this extensive field trials, the product of the movement and song could be better implemented by children and children seem very happy to sing the song.

3. Comparative Study

The development team using test instruments for observing social emotional development of children. The technique used is to compare children's learning outcomes between groups of children who do not use motion and songs and groups of children who use the motion and song in the learning process. TK TK is involved Samporoa as an experimental group and TK Widyatama Tadulako as a control group. The results of the post test between the control group and the experimental group as follows. 
Independent Samples Test

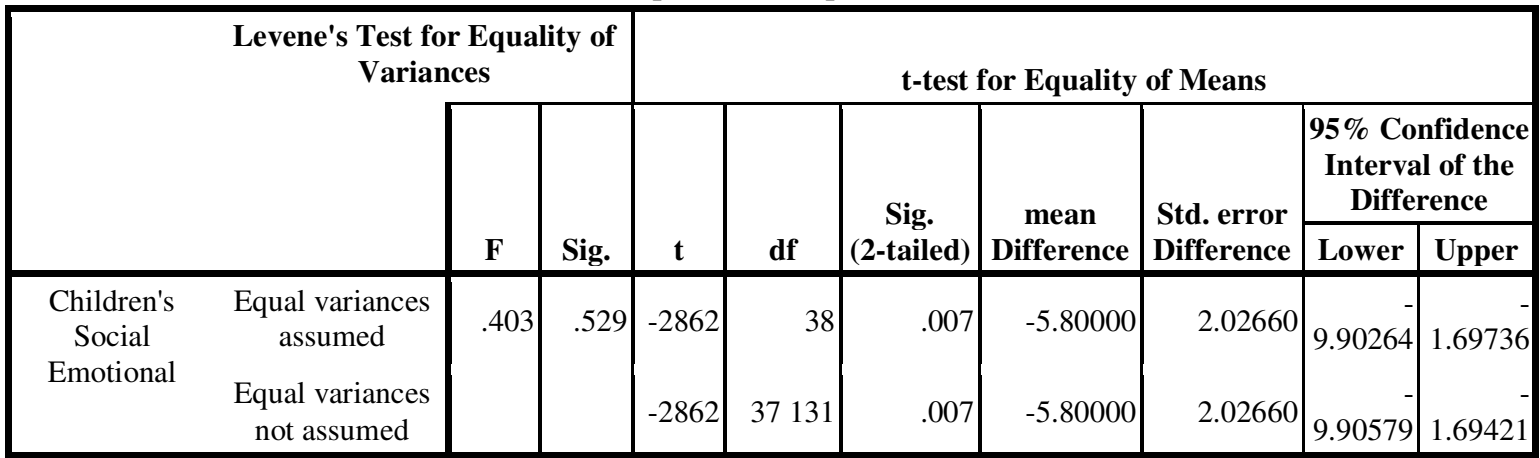

Based on the above output is obtained sig. (2tailed) $0.007<0.05$, it can be concluded Ha accepted which means that "there are significant differences" between the average results of post test control group experimental group.

\section{DISCUSSION}

Motion activity and song is one activity that is very popular with young children. Each child was happy and enjoyed the songs he heard, especially if the song is followed by body movements are simple. Tune of the song raises feeling happy, calm, and happily so as to balance the emotions of children. Through movement and song learning atmosphere would be more fun, the kids amused, and more vibrant. In addition, through the singing together, the child can establish intimacy with their friends so that the resulting self-confidence, love, children are more sociable, to interact, solve problems and socialize with people around.

Based on the results of tests on the motion and a song that was developed by a team of developers, there are several input and advice from a team of validators that product in the form of motion and song can be said to be feasible. Due diligence taken by including validation of subject matter experts, linguists, art expert, limited field trial, extensive field trials and comparison test. Results limited field trial gained an average of 3.34 with a decent criteria, the results of extensive field trial gained an average of 3.52 with a decent criteria, and the results of a comparative study obtained sig. (2-tailed) of $0.007<0.05$, it can be concluded that there are significant differences between the average post test results with a control group experimental group

The results of these tests in accordance with the theory of Santrock (2007: 23) that the motion and the song is a tune that cause feelings into everyday behavior so that children have a place to explore themselves, self-awareness, and emotional balance.

Through movement activities and songs, a child can release the tension they experienced because of the many restrictions that experienced in everyday life. Simultaneously the child can meet the needs and impulses from within yourself that may not be satisfied in real life. If the child can channel feelings of tension, stress, and distribute impulses that arise in him, at least will make the child relieved and relaxed. Of play activities by a group of friends will have a child against her assessment of the advantages that children have that can help to build a positive self-concept, have a sense of confidence and selfesteem. Children feel have the confidence and self-esteem for children to feel a certain competence.

\section{CONCLUSION AND SUGGESTION}

Creativity movement and songs for children can be developed using research stages of R \& D models Borg \& Gall to follow the ten stages of development. Results limited field trial involving 20 children in kindergarten Melati tondo obtain an average result that is equal to 3.34 with the criteria of "decent". Then extensive field trials involving 20 children gained an average yield of 3.52 with the criteria of "decent", and the results of a comparative study obtained sig. (2-tailed) $0.007<0.05$, that "there is a difference significant "between the average results of post test control group experimental group. It can be concluded that creativity can stimulate the movement of social and emotional songs early childhood.

\section{Suggestion}

Based on the research that has been done, then there are some suggestions that will be presented as follows.

1) For parents, should always stimulate the child in a variety of development, especially for children's social and emotional development. The stimulation can be a movement activities and songs through media cassettes, video clips, or teaching directly.

2) For the teacher, the teacher should be able to create and use learning methods that are innovative, varied, creative, and interactive to make the learning process to understand children.

\section{REFERENCES}

[1] Aisyah, Siti.Perkembangan dan Konsep Dasar Pengembangan Anak Usia Dini. 2011.Jakarta: Universitas Terbuka.

[2] Hurlock, Elizabeth. Perkembangan Anak Jilid 1. 2009. Jakarta: Erlangga.

[3] Minet, Pamela. Child Care and Development. 1994. London: John Murray Pub Ltd.

[4] Rachmi, Tetty dkk.Keterampilan Musik dan Tari. 2008. Jakarta: Penerbit Universitas Terbuka. 


\section{ATLANTIS
PRESS}

Advances in Social Science, Education and Humanities Research, volume 449

[5] Santoso, Soegeng.Pendampingan Perkembangan Anak Usia Dini Menurut Pendirinya.

[6] Santrock, John W. 2007. Perkembangan Anak. Jakarta: Erlangga.2004. Jakarta: Depdikbud.

[7] Slavin, Robert E.Psikologi Pendidikan Teori dan Praktik. 2011. Jakarta: Indeks. 